\begin{tabular}{|c|c|}
\hline Journal STAND: Sports and Development & http://jurnal.unipasby.ac.id/index.php/stand/about/submissions \\
unipa Sunabaya & jurnal.stand@unipasby.ac.id
\end{tabular}

\title{
HUBUNGAN STATUS GIZI DENGAN TINGKAT KONSENTRASI SISWA SMP NEGERI 1 NGUNUT TULUNGAGUNG
}

\author{
Muhammad Kharis Fajar ${ }^{1}$ \\ Fakultas Ilmu Olahraga, Universitas Negeri Surabaya \\ email: muhammadfajar@unesa.ac.id ${ }^{1}$
}

\begin{tabular}{l}
\hline Artikel Info \\
\hline Koresponden penulis: \\
Muhammad Kharis Fajar \\
Email. \\
muhammadfajar@unesa.ac.id \\
$\square$ Diterima 22 April 2020 \\
$\square$ Direview 12 Mei 2020 \\
$\square$ Disetujui 13 Mei 2020 \\
$\square$ Dipublikasi 27 Mei 2020
\end{tabular}

Kata Kunci:

Status Giri, Tingkat Konsentrasi,

Siswa SMP

Keywords:

Nutrition Status, Concentration Level, Middle School Students

\begin{abstract}
Abstrak
Tujuan dari penelitian ini adalah untuk mengetahui hubungan tingkat status gizi dengan tingkat konsentrasi siswa SMP Negeri Ngunut 1 Tulungagung kelas VIIG dan VIIH. Penelitian ini merupakan penelitian non eksperimen melalui pendekatan kuantitatif dengan desain korelasional. Subyek dalam penelitian ini sebanyak 72 siswa. Instrument dalam penelitian ini menggunakan penilaian status gizi berdasarkan indeks antropometri dengan berat badan menurut umur BB/U. Tes KOnsentrasi menggunakan Grid concentration Exercise. Sedangkan untuk analisis data dalam penelitian ini menggunakan koefisien kontingensi. Berdasarkan hasil perhitungan diketahui nilai terendah dari hasil tingkat status gizi siswa dalah $5(6,9 \%)$ sedangkan nilai normal 67 $(93,1 \%)$ sedangkan nilai tertinggi 0 . Sedangkan untuk nilai terendah dari hasil tes konsentrasi adalah $34(47,2)$ sedangkan nilai normal $37(51,4 \%)$ dan nilai tertinggi $1(1,4 \%)$. Sedangkan hasil korelasi dilihat dari Sig $=0,412>\alpha=0.05$ artinya Ho diterima, maka tidak ada korelasi (hubungan) yang bermakna antara status gizi dengan tingkat konsentrasi. Koefisien Kontingensi yang di hasilkan adalah 0,155 nilai ini sangat jauh untuk mendekati nilai 1 (satu) menandakan korelasi (hubungan) yang terjadi antara status gizi dengan tingkat konsentrasi adalah lemah.
\end{abstract}

\footnotetext{
Abstract

This study aims to determine the relationship of nutritional status with the concentration level of students of SMP Ngunut 1 Tulungagung VIIG and VIIH classes. This research is a non-experimental research through a quantitative approach with a correlational design. The subjects in this study were 72 students. The instrument in this study used an assessment of nutritional status based on anthropometric indices with body weight according to age BB / U. Concentration test uses Grid concentration exercise. As for the data analysis in this study using contingency coefficients. Based on the calculation results it is known that the lowest value of the results of the nutritional status of students is $5(6.9 \%)$ while the normal value is $67(93.1 \%)$ while the highest value is 0 . While the lowest value of the concentration test results is 34 (47.2) while the normal value is $37(51.4 \%)$ and the highest value is $1(1.4 \%)$. While the results of the correlation seen from $\mathrm{Sig}=0.412>\alpha=0.05$ means that Ho is accepted, then there is no significant correlation (relationship) between nutritional status and the level of concentration. The contingency coefficient produced is 0.155 , this value is very far to approach the value of 1 (one) indicating the correlation (relationship) that occurs between nutritional status with the level of concentration is weak.
} 


\begin{tabular}{|c|c|c|}
\hline Journal STAND: Sports and Development & http://jurnal.unipasby.ac.id/index.php/stand/about/submissions \\
unipa Sumalay & jurnal.stand@unipasby.ac.id
\end{tabular}

\section{PENDAhULUAN}

Gizi menjadi masalah yang penting bagi anak sekolah, karena gizi bisa menunjang kecerdasan anak. Kekurangan gizi menyebabkan mudah mengantuk dan kurang bergairah yang dapat mengganggu proses belajar di sekolah dan menurunnya prestasi belajar, daya pikir anak akan kurang, karena pertumbuhan otaknya tidak optimal. Orang tua perlu memberikan perhatian pada anak usia sekolah menengah pertama (SMP), karena pada umumnya disibukkan dengan berbagai kegiatan di luar rumah cenderung melupakan waktu makan termasuk kebiasaan makan pagi yang cukup akan memenuhi kebutuhan energy selama belajar di sekolah, yang dapat mencegah penurunan kadar gula darah yang berakibat pada terganggunya konsentrasi anak pada saat proses belajar. (http://.rajawana.com/artikel/kesehatan/407-

kebutuhan-gizi-seimbang.html diakses 20 Desember 2010)

Menurut Direktorat Bina Gizi Masyarakat (1994) (dalam hidayat 1999) gizi kurang, banyak di derita anak sekolah yaitu sebesar 30\%. Hasil survei terhadap 600.000 siswa SD di ketahui bahwa siswa SD hanya mengkonsumsi sekitar $70 \%$ dari kebutuhan energy perhari. Padahal gizi kurang dapat menyebabkan gangguan motivasi belajar, gangguan kemampuan berkonsentrasi dan tidak bergairah.

Menurut Efendi (Departemen Ilmu Faal FK Universitas Airlangga) hilangnya atau sulitnya berkonsentrasi dapat disebabkan dua hal yaitu sebab fisiologis dan patologis. Fisiologis tidak berkaitan dengan penyakit tertentu, kaitannya cenderung ke gangguan mental dan kelelahan fisik, rasa sedih, cemas, bingung, marah, perasaan seperti itu bisa menimbulkan gangguan mental, tubuh yang lelah karena sering dipaksa beraktifitas merupakan penyebab lain gangguan konsentrasi. Patologis berkaitan dengan sistem syarat pusat di otak. Gangguan tersebut muncul ketika otak sebagai pengatur segala aktifitas organ tidak mendapatkan cukup aliran darah dan kekurangan oksigen sehingga system syaraf pusat tidak bekerja maksimal (Jawa Pos 12 Desember 2010: 5).

Apabila keadaan ini tidak segera di atasi maka akan menyebabkan anak kekurangan gizi sehingga sulit untuk berkonsentrasi pada saat menerima pelajaran dan akan berdampak pula terhadap ketuntasan proses belajar mengajar baik teori maupun tugas gerak yang diharapkan oleh guru pendidikan jasmani di sekolah.

Berdasarkan pengamatan peneliti di Kecamatan Ngunut terdapat salah satu SMP favorit yaitu SMP Negeri 1 Ngunut Tulungagung. Pada sekolah ini hasil akademik relative baik. Hasil tersebut bisa di capai apabila siswa mempunyai tingkat konsentrasi yang baik dan di dukung dengan status gizi yang baik tentunya.

Hal tersebut diatas menjasi acuan peneliti untuk mengetahui apakah ada hubungan antara status gizi dengan tingkat konsentrasi siswa SMP Negeri 1 Ngunut Tulungagung.

Volume 1 Nomor 1 Tahun 2020 | 36 


\begin{tabular}{|c|c|}
\hline unipa Sumalaya & $\begin{array}{c}\text { Journal STAND: Sports and Development } \\
\text { http://jurnal.unipasby.ac.id/index.php/stand/about/submissions } \\
\text { jurnal.stand@unipasby.ac.id }\end{array}$ \\
\hline
\end{tabular}

\section{KAJIAN LITERATUR DAN PEGEMBANGAN HIPOTESIS (JIKA ADA)}

Menurut Obert Dilts \& Jenifer Dilts (dalam Fitriani 2004:10) yang telah meneliti tentang kesulitan berkonsentrasi mengikuti pelajaran pada anak sekolah dasar. Konsentrasi adalah kecakapan yang bisa diajarkan oleh para orang tua dan guru, konsentrasi juga mengandung pengertian memusatkan pikiran untuk melakukan sesuatu contoh anak yang sedang membaca jika anak berkonsentrasi maka anak akan tahu isi bacaan yang sedang dibaca, tetapi jika anak tidak berkonsentrasi anak-anak maka anak tidak akan tahu isi bacaan tersebut. Konsentrasi dibutuhkan tidak hanya saat belajar, bekerja juga membutuhkan konsentrasi.

Menurut Obert Dilts \& Jenifer Dilts (dalam Fitriani 2004:10) Anak yang belajar berkonsentrasi akan menjadi anak yang tidak membosankan, karena mereka tahu apa yang harus mereka lakukan saat berkonsentrasi. Anak-anak yang bisa berkonsentrasi memiliki keunikan. Keunikan ini bukanlah suatu masalah sejauh tidak menyebabkan masalah bagi orang lain, intelegensia ternyata merupakan bagian kecil dalam mensukseskan belajar anak, soft skill seperti kemampuan konsentrasi lebih berperan dalam prestasi anak di sekolah, konsentrasi bisa diperbaiki dengan pemberian nutrisi dan suplemen yang tepat. Orang tua dan guru sering mengira konsentrasi adalah soal kemauan. Akibatnya anak sering dipaksa berkonsentrasi.
Konsentrasi adalah sebuah keterampilan yang bergantung pada faktor usia, ekspekstasi, dan lingkungan. Menurut Dr. Laurie McNelles, ahli perkembangan anak dan remaja sekaligus direktur Mothercraft Institute for Early Development, York University di Toronto, Kanada. Kemampuan remaja dalam berkonsentrasi lebih baik dari pada anak yang lebih muda. Dr. McNelles, telah mengembangkan keterampilannya untuk mengatur kemampuan berkonsentrasi, sehingga mereka tidak terpecah konsentrasinya. Sementara anak-anak kecil yang lebih kecil mudah terpecah konsentrasinya. (http://www.p3gizi.litbang.depkes.go.id/index.p hp?option=com_content\&task=view\&id=56\&Ite mid=2 diakses 20 Desember 2010).

Menurut Dr. McNellles konsentrasi bisa dimaksimalkan jika anak punya pasokan energi yang cukup untuk otaknya sebelum berangkat sekolah. "Nutrisi yang baik untuk otak, olahraga, dan tidur cukup akan membantu anak untuk berkonsentrasi saat di sekolah,”. (http://www.p3gizi.litbang.depkes.go.id/index.p hp?option=com_content\&task=view\&id=56\&Ite mid=2 diakses 20 Desember 2010)

Otak membutuhkan energi lumayan banyak, sekitar 20 sampai 30 persen energi total dalam tubuh digunakan untuk bahan bakar otak. Boleh di bilang otak adalah organ tubuh yang boros energi. Sudah butuh banyak energi, otak juga hanya menyimpan sedikit energi setiap waktu. Tak heran supaya berfungsi dengan baik. (http://www.p3gizi.litbang.depkes.go.id/index.p 


\begin{tabular}{|c|c|}
\hline unipa Sumalaya & $\begin{array}{c}\text { Journal STAND: Sports and Development } \\
\text { http://jurnal.unipasby.ac.id/index.php/stand/about/submissions } \\
\text { jurnal.stand@unipasby.ac.id }\end{array}$ \\
\hline
\end{tabular}

hp?option $=$ com_content $\&$ task $=$ view $\&$ id $=56 \&$ Ite mid=2 diakses 20 Desember 2010). Selain itu menurut Efendi dari Departemen Ilmu Faal FK Universitas Airlangga hilangnya atau sulitnya berkonsentrasi dapat disebabkan dua hal yaitu sebab fisiologi dan patologis. (Jawa Pos 12 Desember 2010:5)

Jadi konsentrasi adalah memusatkan pikiran untuk melakukan sesuatu. Konsentrasi dibutuhkan tidak hanya saat belajar, bekerja serta berkomunikasi dengan orang lain konsentrasi bisa dimaksimalkan jika anak punya pasokan energi yang cukup untuk otaknya. Olahraga dan tidur yang cukup akan membantu anak untuk dapat berkonsentrasi dengan baik.

Menurut Gunarsa (2004:92) hambatan yang dapat mengganggu kegiatan konsentrasi antara lain:

a. Objek yang terlalu banyak dan peralihan yang terlalu cepat

b. Jika obyek terlalu banyak dan terjadi peralihan yang sangat cepat maka konsentrasi akan mudah terusik.

c. Hubungan antara konsentrasi dan stress

d. Ketegangan yang berlebihan dapat menyebabkan gangguan pada proses berfikir dan kegiatan dari otot yang selanjutnya dapat mengakibatkan kekacauan konsentrasi.

e. Rasa sakit

f. Faktor lain yang dapat menurunkan kemampuan atlet untuk mengubah perhatian dan konsentrasi adalah ketika rangsang lain yang kuat dan sulit dihindari. Salah satu rangsang yang sangat kuat dan besar pengaruhnya adalah rasa sakit. Tanpa adanya keterampilan untuk memusatkan perhatian dengan kuat, maka rasa sakit seperti cidera akan berpengaruh terhadap penampilan atlet.

Jadi, rasa sakit dan faktor lingkungan adalah dua faktor yang dapat mempengaruhi tingkat konsentrasi seseorang. rasa sakit akan sangat berpengaruh terhadap pemusatan pikiran seseorang yang menyebabkan sulit berkonsentrasi. Sedangkan faktor lingkungan yang meliputi keadaan gizi lebih berperan dalam tingkat konsentrasi itu sendiri.

\section{METODE PENELITIAN}

Dalam penelitian ini instrumen yang digunakan untuk pengumpulan data adalah kategori tes. Adapun alat ukur yang digunakan untuk penelitian adalah sebagai berikut:

1. Pengukuran status gizi dengan menggunakan indeks antropometri berdasarkan indikator $\mathrm{BB} / \mathrm{U}$ untuk memperoleh status gizi siswa dimana alatalat yang diperlukan adalah sebagai berikut:

a) Timbangan berat badan.

b) Alat tulis

c) Buku tulis

d) Blangko Grid Concentration Exercise. (untuk mengukur tingkat konsentrasi).

Pelaksanaan penelitian pengukuran status gizi menggunakan indeks antropometri diadakan pada hari Sabtu tanggal 9 April 2011 dan 12 April 2011 di lapangan bola basket SMP Negeri 


\begin{tabular}{|c|c|}
\hline & Journal STAND: Sports and Development \\
unipa Smaltana & $\begin{array}{c}\text { ht/jurnal.unipasby.ac.id/index.php/stand/about/submissions } \\
\text { jurnal.stand@unipasby.ac.id }\end{array}$
\end{tabular}

1 Ngunut, untuk tes konsentrasi dilakukan setelah penelitian pengukuran status gizi dalam ruang kelas yang jauh dari keramaian. Menurut Harris \& Harris (Jannah dalam Era, 2010: 37), untuk konsentrasi dapat diukur dengan menggunakan tes bernama "Grid Concentration Exercise". Tes ini memiliki tujuan untuk mengetahui tingkat konsentrasi seseorang (testee) yang berupa tabel yang memuat angka 0-99. Subyek diminta menghubungkan dengan garis angka-angka tersebut dari angka terkecil sampai angka terbesar dalam waktu satu menit.

Untuk tes tingkat konsentrasi siswa di beri blangko Grid Concentration Exercise. Pada abaaba "ya" siswa mengerjakan dengan cara menghubungkan garis angka-angka dari angka yang terkecil ke angka berikutnya yang lebih besar dalam waktu satu menit

Peraturan: pelaksanaan dilakukan bersama-sama serta dilaksanakan dalam ruangan tenang.

Skor: penilaian dilakukan dengan menghitung perolehan angka tertinggi yang dicapai dikurangi kesalahan yang dilakukan. Semakin tinggi skor yang diperoleh semakin tinggi tingkat konsentrasi.

$0-10$ : rendah

$11-20$ : sedang

$21-30$ : tinggi

\begin{tabular}{rrrrrr}
84 & 27 & 51 & 78 & 59 & 52 \\
\hline 13 & 85 & 61 & 55 &
\end{tabular}

\begin{tabular}{llllll}
28 & 60 & 92 & 04 & 97 & 90 \\
\hline
\end{tabular}

\begin{tabular}{rrrrrr}
32 & 9 & 65 & 39 & 80 & 77 \\
\hline 49 & 86 & 18 & 70 &
\end{tabular}

\begin{tabular}{rrrrrr}
76 & 87 & 71 & 95 & 98 & 81 \\
\hline 01 & 46 & 88 & 00 &
\end{tabular}

\begin{tabular}{llllll}
48 & 82 & 89 & 47 & 35 & 17 \\
\hline
\end{tabular}

\begin{tabular}{llllll}
44 & 67 & 93 & 11 & 07 & 43 \\
\hline
\end{tabular}

\begin{tabular}{llllll}
53 & 79 & 05 & 22 & 54 & 74 \\
\hline
\end{tabular}

\begin{tabular}{llllll}
06 & 68 & 99 & 75 & 26 & 15 \\
\hline
\end{tabular}

\begin{tabular}{llllll}
50 & 09 & 64 & 08 & 38 & 30 \\
\hline 36 & 45 & 83 & 24 &
\end{tabular}

\begin{tabular}{rrrrrr}
03 & 73 & 21 & 23 & 16 & 37 \\
\hline 25 & 19 & 12 & 63 &
\end{tabular}

Blangko Grid Concentration Exercise (dalam Jannah,2004:106)

\section{Teknik Analisis Data}

Penelitian ini menggunakan teknik analisis data, yaitu koefisien kontingensi. Arikunto (2006: 290) menyatakan "koefisien kontingensi digunakan apabila variabel yang dikorelasikan berbentuk kategori”.

Koefisien Kontingensi

$\mathrm{Fh}=$ (jumlah baris) $/$ (jumlah semua) $\mathrm{x}$ jumlah kolom

$\left.\mathrm{x} 2=\sum\left(\mathrm{f} \_0-\mathrm{f} \_\mathrm{h}\right) 2\right) / \mathrm{f}$ h

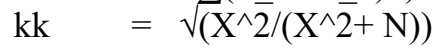

Keterangan:

$\mathrm{x} 2=$ Chi-kuadrat

f0 = Jumlah siswa dalam sel

$\mathrm{kk}=$ Koefisien kontingensi

$\mathrm{N}=$ jumlah seluruh siswa

(Arikunto, 2006: 290). 


\begin{tabular}{|c|c|}
\hline Journal STAND: Sports and Development \\
unipa Sumalama
\end{tabular} $\begin{gathered}\text { htt//jurnal.unipasby.ac.id/index.php/stand/about/submissions } \\
\text { jurnal.stand@unipasby.ac.id }\end{gathered}$

\section{HASIL DAN PEMBAHASAN}

\section{a. Hasil}

Berdasarkan hasil perhitungan yang dilakukan, karena data variabel status gizi berupa data skala ordinal (rangking/peringkat/kategori) yaitu status gizi lebih diberi rangking 3 , status gizi normal diberi rangking 2, dan status gizi kurang diberi rangking 1 maka hanya dilakukan perhitungan frekuensi saja berdasarkan status gizi yaitu gizi lebih sebanyak 0 anak $(0 \%)$ status gizi normal sebanyak 67 anak (93,1\%), status gizi kurang sebanyak 5 anak $(6,94 \%)$.

Maka selanjutnya adalah mencari koefisien antara variabel $\mathrm{X}$ status gizi dengan variabel $\mathrm{Y}$ tingkat konsentrasi siswa. Karena data variabel bebas yaitu status gizi berskala ordinal (rangking/peringkat/kategori) dan data variabel terikatnya juga data ordinal (rangking/peringkat/kategori), sehingga perhitungan korelasinya menggunakan koefisien kontingensi.

Tabulasi Silang antara Status gizi dengan tingkat konsentrasi

Konsentrasi Total

Rendah Sedang Tinggi

Status Gizi Kurang

Normal

Total

\begin{tabular}{llll}
1 & 4 & 0 & 5 \\
\hline 33 & 33 & 1 & 67 \\
\hline 34 & 37 & 1 & 72 \\
\hline
\end{tabular}

Dari tabel tabulasi silang antara tingkat status gizi kurang dan konsentrasi rendah adalah 1 siswa, siswa dengan tingkat status gizi kurang dan konsentrasi sedang adalah 4 siswa, dan siswa dengan tingkat status gizi kurang dan konsentrasi tinggi adalah 0. Sedangkan status gizi normal dengan tingkat konsentrasi rendah adalah 33 siswa, siswa dengan tingkat status gizi normal dengan tingkat konsentrasi sedang adalah 33, sedangkan tingkat status gizi normal dengan tingkat konsentrasi tinggi adalah 1 siswa.

Sedangkan dari hasil uji statistik mengukur koefisien kontingensi didapatkan hasil sebagai berikut

\section{Koefisien Kontingensi Variabel Nilai}

Sig. Status gizi terhadap tingkat konsentrasi

\section{$0.155 \quad 0.412$ Nilai Total 72}

Dilihat dari hasil Sig $=0.412>\alpha=0,05$ artinya Ho diterima, maka tidak ada korelasi (hubungan) yang bermakna antara status gizi dengan tingkat konsentrasi

Koefisien kontingensi yang dihasilkan adalah 0,155 nilai ini sangat jauh untuk mendekati nilai 1 (satu) menandakan korelasi (hubungan) yang terjadi antara status gizi dengan tingkat konsentrasi adalah lemah. Hal ini dapat disimpulkan bahwa variabel $\mathrm{X}$ status gizi tidak mempunyai hubungan yang signifikan dengan variabel $\mathrm{Y}$ tingkat konsentrasi siswa.

\section{b. Pembahasan}

Untuk menunjang tingkat konsentrasi siswa banyak faktor yang mempengaruhinya, salah satu diantaranya adalah status gizi yang baik pada siswa SMPN 1 Ngunut Tulungagung akan sangat menunjang dalam pencapaian tingkat konsentrasi yang optimal. Hal ini menarik minat peneliti untuk mengembangkannya ke dalam penelitian agar mendapat informasi yang pasti 


\begin{tabular}{|c|c|}
\hline Journal STAND: Sports and Development \\
unttp://jurnal.unipasby.ac.id/index.php/stand/about/submissions \\
jurnal.stand@unipasby.ac.id
\end{tabular}

tentang hubungan yang terjadi antara status gizi dengan tingkat konsentrasi siswa SMPN 1 Ngunut Tulungagung.

Dilihat dari hasil $\mathrm{Sig}=0,412>\alpha=0,05$ artinya Ho diterima, maka tidak ada korelasi (hubungan) yang bermakna antara status gizi dengan tingkat konsentrasi

Koefisien kontingensi yang dihasilkan adalah 0,155 nilai ini sangat jauh untuk mendekati nilai 1 (satu) menandakan korelasi (hubungan) yang terjadi antara status gizi dengan tingkat konsentrasi adalah lemah.

Jadi faktor-faktor yang mempengaruhi konsentrasi antara lain usia fisik, jenis kelamin serta pengetahuan dan pengalaman dan asupan gizi yang baik, faktor status gizi pada masa sekarang tidak bisa dibuat patokan untuk mengetahui tingkat konsentrasi siswa SMP Negeri 1 Ngunut Tulungagung. Disini peneliti hanya menilai status gizi dari BB/U tidak sampai pada asupan gizi yang ada pada makanan..

\section{KESIMPULAN}

1. Berdasarkan pada data yang telah terkumpul, diolah, dianalisisa sebagaimana telah dijelaskan pada bab IV secara umum penelitian ini telah menjawab permasalahan yang telah diajukan. Demikian pula pada hipotesis yang merupakan arah kegiatan penelitian ini diuji, maka dapat ditarik simpulan sebagai berikut:

2. Tidak terdapat hubungan yang signifikan antara status gizi dengan tingkat konsentrasi siswa pada SMP Negeri 1 Ngunut Tulungagung

3. Berdasarkan penelitian yang dilakukan bahwa status gizi tidak memberikan sumbangan yang signifikan terhadap tingkat konsentrasi siswa SMP Negeri 1 Ngunut Tulungagung.

\section{REFERENSI}

Almatsier, Sunita.2001. Prinsip Dasar Ilmu Gizi. Jakarta: PT.Gramedia Pustaka utama

Aviana, R., \& Hidayah, F. (2015). Pengaruh Tingkat Konsentrasi Belajar Siswa Terhadap Daya Pemahaman Materi Pada Pembelajaran Kimia Di Sma Negeri 2 Batang. Jurnal Pendidikan Sains Universitas Muhammadiyah Semarang, 3(1), 30-33. https://doi.org/10.26714/jps.3.1.2015.30-33 Arikunto, Suharsimi (2006). Prosedur Penelitian Suatu Pendekatan Prektik. Jakarta. PT Rineka Cipta

Efendi, Choesnan.12 Desember 2010. "Lelah Dan Bosan Konsentrasipun Hilang." Jawa Pos Hal.5.

Fajar, Muhammad Kharis, 2010 Hubungan Status Gizi Terhadap Konsetrasi belajar Siswa SMPN 1 Ngunut. Skripsi Tidak Diterbitkan. Surabaya;Fakultas Ilmu Keolahragaan. Unesa

Fitriani, Yunita.2004. Kesulitan Berkonsentrasi Mengikuti Pelajaran Anak Pada Sekolah Dasar. Skripsi tidak diterbitkan. 


\begin{tabular}{|c|c|}
\hline & Journal STAND: Sports and Development \\
unipa Smaltana & $\begin{array}{c}\text { ht//jurnal.unipasby.ac.id/index.php/stand/about/submissions } \\
\text { jurnal.stand@unipasby.ac.id }\end{array}$
\end{tabular}

Semarang:Fakultas Ilmu Pendidikan UNNES.

Gunarsa, Singgih D. 2004.Psikologi Olahraga Prestasi. Jakarta: BPK Gunung Mulia.

Irianto, Djoko Pekik. 2006. Panduan Gizi Lengkap Keluarga dan Olahragawan. Yogyakarta: Andi Yogyakarta

Jannah, Miftakhul. 2004. Penelitian MeditasiOtogenik Untuk Meningkatkan Konsentrasi Pada Atlet Lari Jarak Pendek. Tesis tidak diterbitkan Yogyakarta: Pasca Sarjana UGM.

Longnecker, D. (2014). Anatomy and Histology of the Pancreas. Pancreapedia: The Exocrine Pancreas Knowledge Base, 1-26. https://doi.org/10.3998/panc.2014.3.

Maksum, Ali (2008). Metodologi Penelitian Dalam Olahraga. Surabaya: Unesa University Press.

Maksum, Ali (2009). Statistik Dalam Olahraga. Surabaya: Unesa University Press.

Monsalves-álvarez, M., Castro-sepúlveda, M., Zapata-lamana, R., Rosales-soto, G., \& Salazar, G. (2015). Original / Pediatría Motor skills and nutritional status outcomes from a physical activity intervention in short breaks on preschool children conducted by their educators: a pilot study, 32(4), 1576-1581. https://doi.org/10.3305/nh.2015.32.4.9514

Pathan, H., \& Williams, J. (2012). Basic opioid pharmacology: an update. British Journal of Pain, 6(1), 11-16. https://doi.org/10.1177/2049463712438493
As, S., Hadju, V., \& Nontji, W. (2013). Nutritional Status in Relations with Development of Gross and Fine Motorics among Child 1-3 Years in Sub District Mangarombang, Takalar Regency 2013, 4531, 410-420.

Sediaoetama, Acmad Djaelani. 1991. Ilmu Gizi Untuk Mahasiswa dan Profesi Jilid 1. Jakarta: Dian Rakyat.

Supariasa Dkk. (2002) Penilaian Status Gizi. Jakarta: Buku Kedokteran EGC.

Triarsana, Diyah.2009. Gizi baik tingkatkan konsentrasi anak, Gaya Hidup Sehat No.502/27Februari Maret 2009 (Online) (http://www.p3gizi.litbang.depkes.go.id/inde $\mathrm{x}$.php?option=com_content\&task=view\&id= 56\&Itemid=2) di akses 20 Desember 2010. 